\title{
УПРАВЛІННЯ СОЦАЛЬНИМИ ПРОЕКТАМИ В УМОВАХ ГЛОБАЛЬНИХ ВИКЛИКІВ: ПРАВОВИЙ ТА ДЕРЖАВНО-УПРАВЛІНСЬКИЙ АСПЕКТИ
}

\author{
РОВНИЙ Віктор Васильович - кандидат юридичних наук, доцент \\ кафедри конституційного права, історії та теорії держави і права ПрАТ «ВНЗ \\ «Міжрегіональна Академія управління персоналом»; \\ ЯЦЕНКО Вікторія Василівна - магістрант ПрАТ «ВНЗ «Міжрегіональна \\ Академія управління персоналом"
}

DOI 10.32782/EP.2020.3.3

Статья посвящена исследованию проектирования и сочиального проектирования, как научных категорий. С челью вылявления особенностей управления сочиальныли проектами, авторами обобщень существующие в отечественной и зарубежной науке подходъ к пониманию категорий «проект», «проектирование», «социальное проектирование».

Установлено, что в отечественной науке имеюшиеся многочисленнье, порой взаимоисключаюшие, крайне узкие, или же наоборот - слишком широкие определения категории «проект». Среди прочего, констатировано отсутствие в украинском научном пространстве единого подхода к пониманию роли проектирования и сощиального проектирования в государственном управлении.

Определено, что больиинство современнъхх исследователей рассматривают социальное проектирование как теоретический прочесс построения моделей, ориентированнъхх на стратегические (в пространстве и времени) масштабъ. Однако, по мнению авторов, уместнее рассматривать сочиальное проектирование во всех его проявлениях, в том числе - локальном и кратковременном.

На основе рассмотрения многочисленньхх определений проектирования и сощиального проектирования, дано авторское определение социиального проектирования, под которьм предлагается понимать творческую деятельность по конструированию целостнъих моделей фбункиционирования уже существуюших, создаваемъгх $u$ перспективных механизмов реализачии определенных иелей, в конкретно-исторических условиях определенного времени и пространства, на основании синтеза теоретических знаний и опьтта в соответствии с потребностями, интересами и ценностями определенного соицального субъекта, в течение прогнозируемого срока и в рамках очерченного объема ресурсов.

Отдельное внимание посвящено процессу децентрализачии, как одному из факторов смещения субъектного состава сочиального проектирования. Отмечено актуальность дальнейшей научной разработки проблематики учета существуноших в украинских, европейских и мировьх масштабах проблем и въизовов обществу, в ходе разработки и реализации социальных проектов.

Ключевъле слова: проект, проектирование, сочиальное проектирование, управление проектами, государственное управление, въззов и угрозы общественным интересам.

Обгрунтування обраної теми дослідження

Наразі в Україні триває комплекс реформ, покликаних сформувати в нашій країні такі суспільні відносини, які відповідатимуть кращим стандартам держав-учасниць ЕС. Серед іншого, відбувається децентралізація, у ході якої сформовано велику кількість територіальних громад та об’єднаних територіальних громад. На останні покладено значну кількість функцій, які раніше виконувалися органами державної влади. Крім того, дедалі більшу роль в процесі захисту прав та законних інтересів громадян, відіграють громадські організації. Одним із ключових завдань держави, територіальних громад, громадських організацій, у 
таких умовах, можна вважати розробку та реалізацію соціальних проєктів, орієнтованих на покращення життя українського народу. Проте, незважаючи на увагу науковців до особливостей проєктування та управління проєктами, у цій сфері лишається чимало питань, що й обумовлює актуальність цього дослідження.

\section{Аналіз попередніх досліджень і публікацій.}

Дослідженню проблематики реалізації соціальних проєктів та управління цими процесами, присвячували свою увагу як вітчизняні, так і зарубіжні науковці. Підгрунтям для даного дослідження стали окремі ідеї, напрацювання таких дослідників як: Г. О. Антонюк, Т. М. Безверхнюк, О. В. Беспалько, Т. І. Бутченко, В. О Дорош, А. О. Аевицький, Р. В. Аеньков, В. А. Ауков, Г. О. Нагорна, К. В. Пєклун, І. О. Прихожан, І. В. Руда, Е. А. Самбуров, I. А. Сенча, Т. В. Сивак, Ж. Т. Тощенко та ін. Однак, висока динаміка сучасного суспільного розвитку, процеси глобалізації на міжнародному рівні та децентралізації на рівні національної політики нашої держави вимагають нових досліджень у цій царині. Серед іншого, потребує окремої уваги науковців проблематика реалізації соціальних проектів з урахуванням загроз і викликів міжнародного та національного масштабу.

Метою статті є дослідження та узагальнення існуючих наукових підходів щодо проєктування, соціального проєктування, в умовах глобальних викликів.

\section{Основний зміст дослідження}

Вітчизняна наукова спільнота вже не перший рік досліджує проблематику проєктування та соціального проєктування. 3 метою конкретизації основних дефініцій, спробуємо здійснити узагальнення понятійно-категоріального апарату.

Відповідно до Словника української мови, проєктування трактується як: а) складання, розробка проекту; б) планування, намічання здійснення чого-небудь [1]. Доволі схожим є визначення дефініцій «проєкт» та «проєктування» у Вебстерському словнику. Проєкт (від англ. project) визначається: по-перше, як конкретний план чи дизайн; по-друге, як ідея чогось; по-третє, як запланований захід. Натомість проєктування розглядається як:а) винайдення, розробка; б) планування, прогнозування i оцінювання майбутнього [2]. О. В. Безпалько серед найбільш поширених понять проєктування виокремлює: а) визначення версій чи варіантів розвитку або зміни певного явища чи об'єкту; б) конструювання варіантів оптимального майбутнього стану об' єкту; в) форму випереджального відображення і перетворення дійсності, спрямована на конструювання системи параметрів майбутнього матеріального об'єкту чи якісно нового його стану; г) прийняття рішень в умовах невизначеності [3, с. 5]. Проте, всі наведені визначення $є$ занадто широкими і дещо абстрактними. Вони не уточнюють ні умов, ні особливостей проєктування. Нам більше імпонує лаконічне, але конкретизоване визначення дефініції «проєкт», укладачів підручника «ннформаційні системи і технології на підприємствах». Зокрема, В. А. Плескач та Т. Г. Затонацька під поняттям «проект» пропонують розуміти «діяльність, спрямовану на створення певного продукту чи послуги протягом визначеного терміну та за певних фінансових обмежень» [4]. Таке визначення видається більш застосовним, оскільки вже в ході теоретичних розробок доречно враховувати всі сучасні в середовищі фактори, а на практиці реалізації проєкту, таке врахування є необхідною умовою успішної реалізації будь-якого проєкту.

Стосовно процесу проєктування, Т. І. Бутченко зазначає, що проєктування в цілому справедливо інтерпретується як прояв зв'язку можливого та дійсного, майбутнього і сучасного і в такому вигляді як неодмінна умова довершення, конституювання цілісності буття особистості у світі. У кінцевому підсумку, здатність людини проектувати світ і себе є основою iї свободи та відповідальності [5, с.147]. Такий підхід може видатися занадто ліричним, як для наукової дискусії, проте в подальшому дослідник наводить більш грунтовну дефініцію, визначаючи «проєктування» як «творчу цілепокладаючу мисленнєву діяльність із конструювання здійсненних, завершених, цілісних ідеальних моделей функціонування нових штучних об’єктів і приписів 3 їх втілення в конкретно-історичних умовах визначеного часу та простору на підставі синтезу теоретич- 


\section{Теорія, історія держави і права, конституційне право}

них знань і практичного досвіду згідно з потребами, інтересами та цінностями певного соціального суб'єкту [5, с. 153]. Частково погоджуючись із наведеним визначенням, вважаємо за потрібне акцентувати увагу на дискусійності «здійсненості» та «завершеності» проєктів. Окрім того, не зовсім зрозуміло, якою мірою можна вести мову про «цілісні ідеальні моделі», якщо мова йде про їх втілення в конкретно-історичних умовах (тобто на практиці).

Ведучи мову про роль проєктування, як процесу державного рівня, Т. М. Безверхнюк стверджує, що необхідність реалізації великомасштабних проєктів призвела до формування нових проектно-орієнтованих інноваційних технологій та механізмів реалізації складних, розрахованих на великий проміжок часу цілей, пов'язаних 3 використанням значних ресурсів, а часто міжвідомчої та міжгалузевої кооперації. При цьому, проєктно-орієнтоване управління розглядається як новий «гнучкий» метод, який забезпечує взаємозв'язок творчих зусиль із загальними задачами керівників. Його суттю є формування цілей управління, виявлення проблем, що вимагають вивчення і ефективного вирішення, розробка програми або стратегічного плану вирішення проблем, усунення перешкод досягненню поставлених цілей [6, с. 83]. У цілому погоджуючись iз дослідницею, зауважимо, що проєктування може мати не лише «стратегічний», але й «тактичний» масштаб, і бути зорієнтованим на вирішення як довготривалих, так і відносно короткочасних цілей.

I. O. Прихожан, наполягаючи на важливості використання проєктування в державному управлінні, обгрунтовує ії необхідністю модернізації економічного та соціального життя держави, впровадження інноваційних технологій управління суспільними процесами. Важливість проєктування в державному управлінні, на переконання дослідника, визначається збільшенням ролі інститутів громадянського суспільства, суспільної експертизи та необхідністю формування структур між секторної взаємодії [7, с. 4-6]. У цілому не заперечуючи важливість інноваційної діяльності та доречність іï врахування в ході проєктування, вважаємо, що проєктування не можна розглядати виключно як сучасне явище, що носить інноваційний характер, оскільки в найбільш широкому значенні, проєктування використовувалося всіма державами протягом відомої історії людства.

Дещо вужчим поняттям, окремим проявом проєктування, є соціальне проєктування. Один із основоположників теорії соціального проєктування Г. О. Антонюк вважає, що соціальне проектування - це розробка науково-обгрунтованої моделі раціональних характеристик конкретних соціальних організмів чи їх станів у контексті вирішення певних соціальних задач [8, с. 37]. Натомість О. В. Безпалько трактує соціальне проєктування як комплексну розробку, спрямовану на створення науково обгрунтованого та затребуваної моделі бажаного майбутнього з метою ії подальшої реалізації в процесі практичної діяльності; побудову конкретних соціальних моделей, прогнозів, заснованих на соціологічних дослідженнях, економічних розрахунках [3, с.14]. При цьому, на переконання дослідника, соціальне проєктування можна визначити як сукупність технологічних, управлінських та організаційних рішень, спрямованих на вирішення соціальних проблем, поліпшення соціокультурних умов життєдіяльності особистості, проведення необхідних соціальних змін [3, с.64].

Доволі детально розглядає особливості соціального проєктування та наявних у вітчизняній і зарубіжній науці підходів до нього Г. О. Нагорна у своєму дисертаційному дослідженні «Соціальне проектування в державному управлінні: теоретичний аспект» [9]. Зокрема, в найширшому значенні, в рамках філософсько-узагальнюючого підходу, дослідниця трактує соціальне проєктування як діяльність, направлену на зміну соціального майбутнього. При цьому, узагальнюючи погляди зарубіжних науковців Г. Хадсона та К. Маккініс, вона доходить висновку, що зарубіжні фахівці в центр уваги ставлять все ж таки людський фактор, на дослідження якого направлено соціальне проектування [9, с. 45-49]. Певною мірою такий підхід можна вважати виправданим, однак, у вітчизняних реаліях, суб'єктом соціального проектування найчастіше виступає держава, і лише останнім часом починає зростати роль територіальних громад чи окремих громадських організацій.

Відповідно до ст. 1 Конституції України, «Україна є суверенна і незалежна, демо- 
кратична, соціальна, правова держава» [10] У цьому контексті термін «соціальна» передбачає визнання державою своєї відповідальності перед власним суспільством. Так, зокрема, відповідно до тлумачення положень ст. 1 Конституції України, Конституційним Судом України, «однією з ознак України як соціальної держави є забезпечення загальносуспільних потреб у сфері соціального захисту за рахунок коштів Державного бюджету України виходячи з фінансових можливостей держави, яка зобов'язана справедливо і неупереджено розподіляти суспільне багатство між громадянами і територіальними громадами та прагнути до збалансованості бюджету України. При цьому рівень державних гарантій права на соціальний захист має відповідати Конституції України, а мета і засоби зміни механізму нарахування соціальних виплат та допомоги принципам пропорційності і справедливості» [11]. Таким чином, уже сьогодні Українська держава бере на себе конституційно закріплені зобов'язання справедливо і неупереджено розподіляти суспільне багатство між громадянами і територіальними громадами. Особливий науковий інтерес для сучасних дослідників соціального проєктування має становити проблема формування єдиної державної політики щодо сприяння соціальним проєктам, спрямованим на виявлення, обмеження та (за можливості) усунення загроз суспільству. При цьому, варто враховувати, що такі проекти можуть мати (і в умовах децентралізації - дедалі частіше матимуть) локальний масштаб.

\section{Висновки і перспективи подалыших досліджень}

Узагальнюючи наявні у вітчизняній та зарубіжній науці підходи до визначення понять «проєктування» та «соціальне проєктування», пропонуємо під соціальним проєктуванням розуміти творчу діяльність із конструювання цілісних моделей функціонування вже наявних, новостворених та перспективних механізмів реалізації окреслених цілей у конкретно-історичних умовах визначеного часу та простору на підставі синтезу теоретичних знань і практичного досвіду згідно з потребами, інтересами та цінностями певного соціального суб'єкта, протягом прогнозованого терміну та в рамках окресленого обсягу ресурсів.
Наразі малодослідженою та такою, що потребує подальшої наукової розробки, видається проблематика врахування наявних в українських, європейських та світових масштабах проблем і викликів суспільству, у ході розробки і реалізації соціальних проєктів.

\section{Мiтература}

1. Словник української мови: в 11 томах. Том 8, 1977. Стор. 177. URL http://sum. in.ua/s/proektuvannja

2. project. merriam-webster. URL: https:// www.merriam-webster.com/dictionary/project

3. Безпалько О.В. Соціальне проєктування: навч. посіб. / Київ. ун-т ім. Б. Грінченка, Ін-т психології та соц. педагогіки, . К. : [б. в.], 2010. 127c.

4. В. ^. Плескач та Т. Г. Затонацька Iнформаційні системи і технології на підприємствах. Підручник. Знання, Київ. 2011. 718 с.

5. Бутченко Т. І. Зміст поняття «проектування» // Гуманітарний вісник Запорізької державної інженерної академії: електрон. версія журнал. 2009. Вип. 37. С. 144-154. URL. http://nbuv.gov.ua/j- pdf/znpgvzdia 2009 $37 \quad 17$. pdf

6. Управління проектами в публічній сфері: навч. посібн. / Т. М. Безверхнюк, Н.О. Котова, С.А. Попов / за заг. ред. Безверхнюк Т. М. Одеса: ОРІДУ НАДУ, 2011. 295 с.

7. Прихожан И.А. Управление социальным проектом: практикум для руководителей и активистов социально ориентированных некоммерческих организаций / Волгогр. ин-т гражданского общества, Центр гражданского образования. Волгоград : Фортесс, 2017. 347с.

8. Антонюк Г.А. Социальное проектирование и управление общественным развитием : теоретико-методологический аспект. Минск : Наука и техника, 1986. 193с.

9. Нагорна Г. О. Соціальне проектування в державному управлінні: теоретичний аспект. дис... . канд. держ упр. наук. Одеса, Івано-Франківск, 2018. 227 с.

10. Конституція України: Закон України № 254к/96-ВР від 28червня 1996 р. URL: $\underline{\text { https:// }}$ zakon.rada.gov.ua/laws/show/254\%D0\%B/96\%D0\%B2\%D1\%80\#Text

11. Рішення Конституційного Суду України у справі за конституційним поданням правління Пенсійного фонду України 25 січня 2012 року № 3-рп/2012 URL: https://zakon.rada. gov.ua/laws/show/v003p710-12\#n54 
The article is devoted to the study of projects and social projects as scientific categories. In order to identify the features of social project management, the authors summarize the existing approaches in domestic and foreign science to understand the categories of "project", " the processes of a projecting", "the processes of a social projecting".

It was found that in domestic science there are numerous, sometimes mutually exclusive, extremely narrow, or, conversely, too broad definitions of the category "project". Among other things, it is stated that there is no unified approach to understanding the role of project process and social project process in public administration in the Ukrainian scientific space.

It is determined that most modern researchers consider the processes of a social projecting as a theoretical process of building models focused on strategic (in space and time) scale. Instead, according to the authors, it is more appropriate to consider the processes of a social projecting in all its manifestations, including local and short-term.

Based on the consideration of numerous definitions of project and the processes of a social projecting, the author's definition of the processes of a social projecting, which is proposed to understand the creative activity of constructing holistic models of existing, just created and promising mechanisms for realizing of the outlined goals in specific historical conditions of time and space, whis included knowledge and practical experience in accordance with the needs, interests and values of a particular social entity, during the projected period and within the specified amount of resources.

Particular attention is paid to the process of decentralization, as one of the factors shifting the subjective composition of social project. Emphasis is placed on the urgency of further scientific development of the issues of taking into account the existing problems in Ukraine, European and world scale and challenges to society, in the development and implementation of social projects.

Key words: project, the processes of a projecting, the processes of a social projecting, project management, public administration, challenges and threats to public interests. 